\title{
Growth, Plant Quality, and Survival of Sweet Cherry (Prunus avium L.) Seedlings are Enhanced by $\mathrm{CO}_{2}$ Enrichment
}

\author{
Margarita Pérez-Jiménez ${ }^{1}$, Almudena Bayo-Canha, Gregorio López- \\ Ortega, and Francisco M. del Amor \\ Departamento de Hortofruticultura, Instituto Murciano de Investigación y \\ Desarrollo Agrario y Alimentario (IMIDA), Murcia 30150, Spain
}

Additional index words. carbon dioxide, Prunus, breeding, cherry, photosynthesis, acclimatization

\begin{abstract}
Enrichment with $\mathrm{CO}_{2}$ and a commercial mix of plant growth regulators were tested to improve the plant quality and survival of pregerminated cherry tree seedlings. Pregerminated seeds were transferred from a cold chamber to a climatic chamber where the $\mathrm{CO}_{2}$ was set at $800 \mu \mathrm{mol} \cdot \mathrm{mol}^{-1} \mathrm{CO}_{2}$ or at the ambient $\mathrm{CO}_{2}$ concentration. Also, half of the plants were sprayed with the mix of plant growth regulators and disposed randomly. The experiment lasted 18 days and physiological measurements, such as plant physiological status and growth, number of leaves, net $\mathrm{CO}_{2}$ assimilation $\left(\mathrm{A}_{\mathrm{CO} 2}\right)$, internal $\mathrm{CO}_{2}$, stomatal conductance, and transpiration, were taken every 4 days. Also, at the end of the experiment, other parameters - such as total leaf area, photosynthetic pigments, soluble sugars, and starch-were recorded or quantified. During the experiment, plants cultured under $\mathrm{CO}_{2}$ enrichment exhibited a rapid increase in their photosynthetic rates, height, and leaf number; the commercial mix also increased plant height but inhibited leaf expansion and growth. At the end of the experiment, the amounts of starch and soluble sugars had increased in the plants grown under elevated $\mathrm{CO}_{2}$, compared with those plants grown in control conditions or with the commercial mix. Thus, culture at elevated $\mathrm{CO}_{2}$ achieved higher percentages of plant survival and of plants in active growth. We suggest that $\mathrm{CO}_{2}$ plays an important role-by increasing $\mathrm{A}_{\mathrm{CO} 2}$, water use efficiency, soluble sugars, and starch-which results in plants that are physiologically more prepared for transfer to the field.
\end{abstract}

Cherry (Prunus avium L.) is an important and valuable agricultural and timber crop throughout Europe (Centritto et al., 1999). Therefore, in the last few decades, increasing attention has been paid to solving different problems related to its growth, diseases, and postharvest storage. Breeders have been trying to address these problems, which can be overcome through the performance of assisted crosses in the field (Arbeloa et al., 2009). As a result of these crosses many unique seeds are obtained, which can lead to genetically enhanced cultivars. Thus, seedlings are the key factor of any plant breeding program because each seed is a potential cultivar which may be able to face the market challenges. Breeding programs are composed of many steps, all of which are crucial to the final success. However, acclimatization is not always an easy step and in many species low

\footnotetext{
Received for publication 25 July 2017. Accepted for publication 16 Oct. 2017.

This work was financed by the European Social Fund (ESF) European Union-FEDER 80\%-Región de Murcia (FEDER 1420-07).

We thank David J. Walker for assistance with the correction of the English in the manuscript.

${ }^{1}$ Corresponding author. E-mail: margarita. perez3@carm.es.
}

survival percentages are obtained (Marin, 2003). Thereby, it is crucial to provide a healthy development to ensure high survival rates both in the greenhouse and in the field. Many strategies have been developed to assure seed germination (Sharma et al., 1996) in woody plant breeding programs; however, seedling growth is still conducted under traditional culture conditions. Currently, cherry breeding programs get the lower number of seedlings among the Prunus programs (Carrasco et al., 2013) and the acclimation of seedlings is still one of the weak points in this pathway. For that reason, it is important to develop new strategies that could increase the survival of these new genotypes. Moreover, plants of woody fruit species have long juvenile periods. Hence, any advance in plantlet development can accelerate the first field evaluation and shorten the breeding periods.

It is well known that global climate change is producing a marked increase in the atmospheric $\mathrm{CO}_{2}$ concentration, affecting several physiological processes in plants (Saralabai et al., 1997). The most reported phenomenon induced by high $\mathrm{CO}_{2}$ is an increase in the photosynthetic carbon fixation rates. Plant growth and development are intensely affected by photosynthesis, with the carbon assimilates necessary for yield production ultimately produced via photosynthesis (Wang et al., 2007). Thus, a rise in the photosynthetic rate increases plant growth and development through an increment in carbohydrates production and in the water use efficiency (WUE) (Chaves, 1994). Currently, this responsiveness of plants to elevated $\mathrm{CO}_{2}$ is being used in commercial farms to accelerate plant growth and production (Pérez-Jiménez et al., 2015). Although these physiological effects are remarkable, there is evidence that their magnitude is dependent on other factors (Wullschleger et al., 2002).

Plant growth regulators are widely known as a key factor in many physiological processes, playing a regulatory role in plant growth and development. For instance, gibberellic acid (GA) can be applied to reduce the time of germination in stone fruit seeds (Kuden et al., 1999) and cytokinins activate cell division in meristems, increasing plant growth (Morini and Melai, 2005). In recent years, products have appeared in the market that promote growth and yield by means of plant growth regulators. Especially relevant is the case of Promalin ${ }^{\circledR}$, a commercial formulation $\mathrm{GA}_{4+7}$ plus 6benzyladenine (BA). Promalin ${ }^{\circledR}$ has been used for breaking seed dormancy (Socolowski and Cicero, 2011) and promoting plant growth (Emongor et al., 2004; Goenaga, 2010; Rossi et al., 2004). Furthermore, this product has been reported to promote shoot growth in cherry trees through an increase in cell division and expansion (Veinbrants and Miller, 1981).

This study seeks to enhance seedling growth and survival rates, and hence guarantees the maximum number of seedlings and produces strong plantlets that can tackle field conditions. To this end, in an 18-day experiment, the effects produced by two wellknown plant growth promoters, $\mathrm{CO}_{2}$ and Promalin $^{\circledR}$, were assessed through the study of many relevant physiological parameters, such as height, number of leaves, leaf area (LA), net $\mathrm{A}_{\mathrm{CO} 2}$, transpiration, internal $\mathrm{CO}_{2}$, stomatal conductance $\left(g_{\mathrm{S}}\right)$, photosynthetic pigments, starch, and soluble sugars.

\section{Materials and Methods}

Plant material and experimental conditions. Openly pollinated fruits were harvested from the sweet cherry (Prunus avium L.) cv. Burlat in the field in June 2014. The fruits were collected from 15-year-old trees belonging to a germplasm collection grafted on the $P$. mahaleb rootstock SL 64 (Saint Lucie) from the experimental station 'La Maestra' in Jumilla, Murcia (Spain). A total of 1152 well developed and uniform fruits were selected for the experiment and stored at $0 \pm 1{ }^{\circ} \mathrm{C}$ for a period of $18 \mathrm{~h}$ before use (Fig. 1). The seeds were first removed from the endocarp and washed with running tap water and commercial soap. Then, they were transferred to small bags containing wet perlite and stored at $4 \pm$ $1{ }^{\circ} \mathrm{C}$ for a period of $90 \mathrm{~d}$. After stratification, germinated seeds with a small radicle emergence were transferred to $7 \times 7 \times 8 \mathrm{~cm}$ pots containing a mixture of peat (Prohumin, Projar 

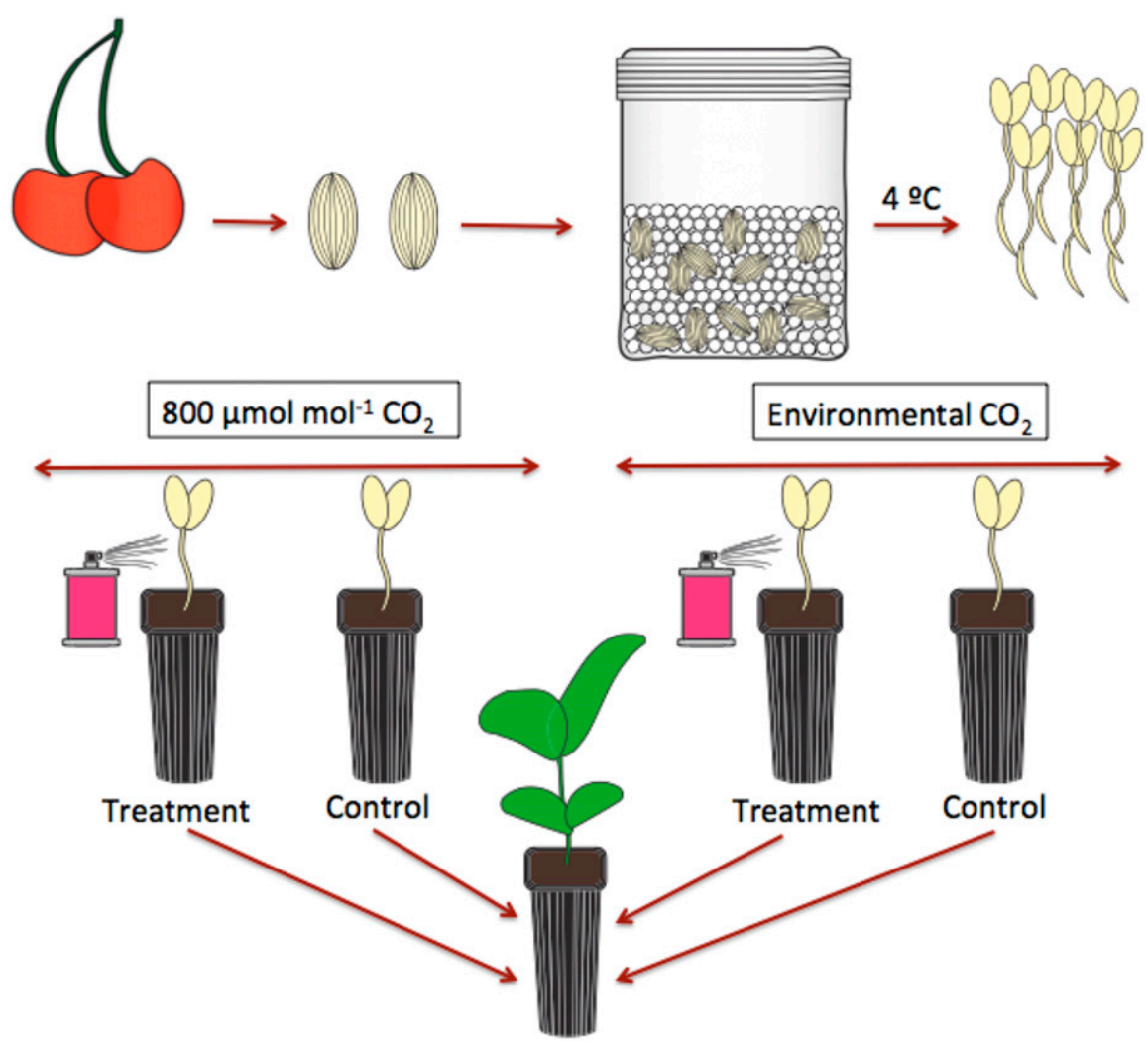

Fig. 1. The experimental design used in the study of the effect of an elevated concentration of $\mathrm{CO}_{2}$ and Promalin $^{\circledR}$ on pregerminated Prunus avium seedlings.

S.A., Valencia, Spain) and perlite (Projar S.A.) in a $3: 1$ ratio and $115 \mathrm{~g}$ of slow-release fertilizer $\quad\left(\right.$ Floranid $^{\circledR}$ permanent Compo, Münster, Germany). The plants were watered frequently to provide enough water to replace water loss. Immediately after planting, the plants were sprayed with an antifungal solution composed of tachigaren and mancozeb (2 $\mathrm{mL} \cdot \mathrm{L}^{-1}$ ); then, half of the plants were sprayed with a solution of $10 \%$ Promalin $^{\circledR}\left(\mathrm{GA}_{4+7}\right.$ $1.9 \%$, w/v + BA 1.9\%, w/v) (Kenogard, Barcelona, Spain) in distilled water. The other plants were also sprayed with the same solution but without Promalin ${ }^{\circledR}$ to avoid any interaction (Fig. 1).

The experiment was performed in a controlled climate chamber designed by our department specifically for plant research purposes (del Amor et al., 2010), with fullycontrolled environmental conditions: $75 \%$ relative humidity, $16 / 8 \mathrm{~h}$ day/night photoperiod, $25 \pm 1{ }^{\circ} \mathrm{C}$, and a photosynthetically active radiation of $250 \mu \mathrm{mol} \cdot \mathrm{m}^{-2} \cdot \mathrm{s}^{-1}$ provided by a combination of fluorescent lamps (TL-D Master reflex 830 and 840; Koninklijke Philips Electronics N.V., Eindhoven, The Netherlands) and high-pressure sodium lamps (Son-T Agro; Philips). The experiment was carried out at $800 \mu \mathrm{mol} \cdot \mathrm{mol}^{-1} \mathrm{CO}_{2}$ and at control $\left(\mathrm{CO}_{2}\right)$ [ambient $\left(\mathrm{CO}_{2}\right), 380 \pm 40$ $\mu \mathrm{mol} \cdot \mathrm{mol}^{-1} \mathrm{CO}_{2}$.

Samples were collected at the time of the transfer to the climate chamber and every $4 \mathrm{~d}$ of treatment up to $18 \mathrm{~d}$. The plant height, number of leaves, and gas exchange parameters were determined. At the end of the experiment, leaf samples were collected, for
LA measurements and further quantifications of photosynthetic pigments, soluble carbohydrates, and starch. The numbers of plants in active growth (new shoots or leaves), in a steady state (no new shoots and no growth), or dead were recorded every $4 \mathrm{~d}$.

Plant growth. Plant height was measured as well as the number of leaves. The LA was also recorded, using a portable area meter (LI-COR Model LI-3000A; LI-COR, Lincoln, NE).

Gas exchange. The net $\mathrm{A}_{\mathrm{CO} 2}$, internal $\left(\mathrm{CO}_{2}\right)(\mathrm{Ci})$, transpiration rate $(\mathrm{E})$, and $g_{\mathrm{S}}$ were measured in the youngest fully expanded leaf of each plant, using a CIRAS-2 (PP System, Amesbury, MA) with a PLC6 (U) Automatic Universal Leaf Cuvette, measuring both sides of the leaves. The cuvette provided light (light-emitting diode) with a photon flux of $1300 \cdot \mathrm{m}^{-2} \cdot \mathrm{s}^{-1}, 400$, or 800 $\mu \mathrm{mol} \cdot \mathrm{mol}^{-1} \mathrm{CO}_{2}$, a leaf temperature of $25^{\circ} \mathrm{C}$, and $75 \%$ relative humidity.

Chlorophyll content. Chlorophylls a (Chl $a), b(\mathrm{Chl} b)$, and $a+b(\mathrm{Chl} a+b)$ were extracted from samples of the youngest leaf with N,N-dimethylformamide, for $72 \mathrm{~h}$, in darkness at $4{ }^{\circ} \mathrm{C}$. Subsequently, the absorbance was measured in a spectrophotometer at 750,664 , and $647 \mathrm{~nm}$, and the quantities were calculated according to the method of Porra et al. (1989).

Soluble sugars and starch. Soluble sugars were extracted according to Walker et al. (2008), by incubating $40 \mathrm{mg}$ of lyophilized leaf tissue twice in $5 \mathrm{~mL}$ of $60 \%$ ethanol, for 30 min each time, at $35^{\circ} \mathrm{C}$. Each extract was centrifuged at $3500 \times g$ for $10 \mathrm{~min}$, at $20^{\circ} \mathrm{C}$, and the two supernatants were combined. Chloroform $(5 \mathrm{~mL})$ was added and the mixture shaken before centrifugation at $2700 \times g$ for $10 \mathrm{~min}$ at $20{ }^{\circ} \mathrm{C}$. The upper, colorless layer $(20 \%$ ethanol) was diluted 4-fold with absolute ethanol to produce an extract in $80 \%$ ethanol for measurement of soluble sugars according to Buysse and Merckx (1993). The residual material from the extraction with $60 \%$ ethanol was hydrolyzed with $3 \% \mathrm{HCl}$, for $3 \mathrm{~h}$ at $125^{\circ} \mathrm{C}$, and the soluble sugars released were measured as an estimate of the starch content.

Data collection and statistical analysis. Four treatments with 288 plants each and 10 replications per sampling were studied. Samples were taken every $4 \mathrm{~d}$. The data were tested first for homogeneity of variance and normality of distribution. Significance was determined by analysis of variance, and the significance $(P<$ 0.05 ) of differences between mean values was tested by Duncan's new multiple range test using Statgraphics Centurion ${ }^{\circledR}$ XVI (StatPoint Technologies, Inc., Warrenton, VA).

\section{Results}

Germinated cherry seeds were cultured at $800 \mu \mathrm{mol} \cdot \mathrm{mol}^{-1} \quad \mathrm{CO}_{2}$ and promalin ${ }^{\circledR}$ was applied. To test their capacity for growth and adaptation in these conditions the experiment was repeated at the ambient concentration of $\mathrm{CO}_{2}$. During the experiment, the plants were classified in three groups: active growth, steady state, and dead plants. As shown in Table 1 , the elevated $\mathrm{CO}_{2}$ concentration increased the number of plants in active growth by almost $10 \%$ when compared with plants cultured in control conditions and by $12 \%$ when compared with plants treated with the Promalin ${ }^{\circledR}$ solution and grown in control conditions. However, the number of plants in a steady state was slightly reduced, by $2 \%$ to $4 \%$, by applying $800 \mu \mathrm{mol} \cdot \mathrm{mol}^{-1}$ $\mathrm{CO}_{2}$ and was unaffected by Promalin ${ }^{\circledR}$ (Table 1). By contrast, the Promalin ${ }^{\circledR}$ treatment produced a higher number of dead plants, exceeding the number observed without Promalin ${ }^{\circledR}$ (Table 1). This effect was more pronounced in the case of plants grown at $800 \mu \mathrm{mol} \cdot \mathrm{mol}^{-1} \mathrm{CO}_{2}$.

Plant growth. Plant growth was evaluated immediately after planting and every $4 \mathrm{~d}$ of treatment up to 18 d. Plant height (Fig. 2) increased gradually from the first day of the experiment in all treatments. Notwithstanding, it significantly increased in those plants sprayed with the Promalin ${ }^{\circledR}$ solution and at elevated $\mathrm{CO}_{2}$. Plants sprayed with Promalin ${ }^{\circledR}$ but cultured at ambient $\mathrm{CO}_{2}$ had grown more than those grown without Promalin ${ }^{\circledR}$ and exposed to ambient $\mathrm{CO}_{2}$ at the end of the experiment. Per contra, no significant differences were found relative to plants grown at $800 \mu \mathrm{mol} \cdot \mathrm{mol}^{-1}$ $\mathrm{CO}_{2}$ without Promalin ${ }^{\circledR}$ exposure.

Leaves (Fig. 2) were more abundant in plants cultured at elevated $\mathrm{CO}_{2}$ and no Promalin ${ }^{\circledR}$. These differences were significant after day 11 and until the end of the experiment. No significant differences were detected among the rest of the treatments. The treatment with 
Table 1. Percentage of Prunus avium seedlings in active growth, in a steady state or dead after being treated with Promalin ${ }^{\circledR}$ and $800 \mu \mathrm{mol} \cdot \mathrm{mol}^{-1} \mathrm{CO}_{2}(\mathrm{P}-800)$ or the ambient concentration of $\mathrm{CO}_{2}(\mathrm{P}-\mathrm{C})$, or without Promalin ${ }^{\circledR}$ in $800 \mu \mathrm{mol} \cdot \mathrm{mol}^{-1} \mathrm{CO}_{2}(\mathrm{C}-800)$ or the ambient concentration of $\mathrm{CO}_{2}(\mathrm{C}-\mathrm{C})$.

\begin{tabular}{|c|c|c|c|c|c|c|c|c|c|c|c|c|c|}
\hline \multirow{2}{*}{\multicolumn{2}{|c|}{$\begin{array}{c}\mathrm{CO}_{2} \\
\text { Treatment } \\
\end{array}$}} & \multicolumn{2}{|c|}{400} & \multicolumn{2}{|c|}{800} & \multicolumn{2}{|c|}{400} & \multicolumn{2}{|c|}{800} & \multicolumn{2}{|c|}{400} & \multicolumn{2}{|c|}{800} \\
\hline & & C & $\mathrm{P}$ & C & $\mathrm{P}$ & C & $\mathrm{P}$ & C & $\mathrm{P}$ & C & $\mathrm{P}$ & C & $\mathrm{P}$ \\
\hline$\overline{\text { Day }}$ & 0 & 100.00 & 100.00 & 100.00 & 100.00 & 0.00 & 0.00 & 0.00 & 0.00 & 0.00 & 0.00 & 0.00 & 0.00 \\
\hline & 7 & 41.84 & 40.63 & 43.92 & 44.79 & 4.86 & 5.38 & 2.95 & 2.78 & 3.30 & 5.73 & 3.13 & 2.43 \\
\hline & 11 & 38.54 & 42.71 & 44.10 & 43.06 & 3.30 & 1.56 & 0.87 & 1.74 & 8.16 & 5.73 & 4.69 & 5.21 \\
\hline & 14 & 40.80 & 39.76 & 44.10 & 40.97 & 1.04 & 2.78 & 0.35 & 0.35 & 8.16 & 7.47 & 5.56 & 8.68 \\
\hline & 18 & 39.24 & 37.85 & 43.92 & 40.10 & 1.39 & 1.91 & 0.35 & 0.00 & 9.38 & 10.24 & 5.73 & 9.90 \\
\hline
\end{tabular}
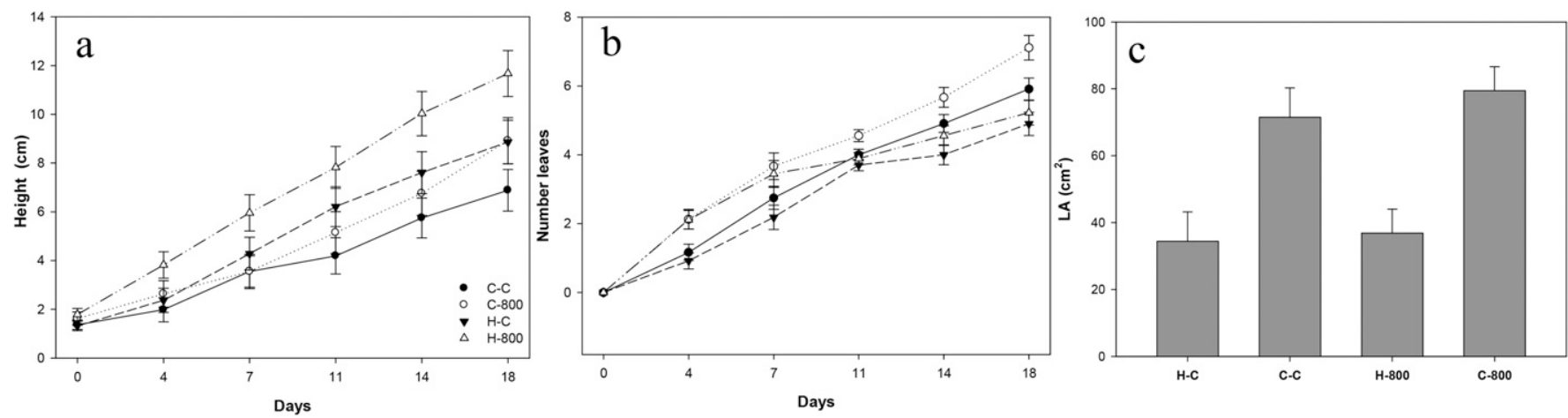

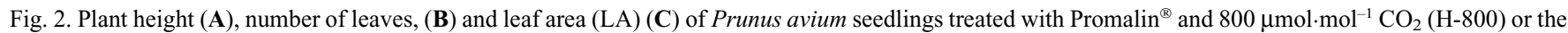
ambient concentration of $\mathrm{CO}_{2}(\mathrm{H}-\mathrm{C})$, or without Promalin ${ }^{\circledR}$ in $800 \mu \mathrm{mol} \cdot \mathrm{mol}^{-1} \mathrm{CO}_{2}(\mathrm{C}-800)$ or the ambient concentration of $\mathrm{CO}_{2}(\mathrm{C}-\mathrm{C})$. Values are means $\pm \mathrm{sE}$ $(n=10)(P<0.05)$.

Promalin ${ }^{\circledR}$ resulted counter-productive in terms of LA (Fig. 2) because the plants sprayed with this treatment exhibited lower LA values than those from the control treatments. No differences were found between the $\mathrm{CO}_{2}$ treatments.

Gas exchange. The $\mathrm{A}_{\mathrm{CO} 2}$ was significantly higher under high $\mathrm{CO}_{2}$ than under control $\mathrm{CO}_{2}$ (Fig. 3). Promalin ${ }^{\circledR}$ treatment did not produce a change in $\mathrm{A}_{\mathrm{CO} 2}$ in plants cultured at the ambient concentration of $\mathrm{CO}_{2}$ and only a decrease on days 7 and 11 in plants cultured at elevated $\mathrm{CO}_{2}$. Dissimilar results were detected for $g_{\mathrm{s}}$ (Fig. 3). Plants cultured with high $\mathrm{CO}_{2}$ had higher $g_{\mathrm{s}}$ than plants cultured at control $\mathrm{CO}_{2}$ up to day 11 , when no significant differences were detected among treatments; after that point, plants grown in high $\mathrm{CO}_{2}$ had lower $g_{\mathrm{s}}$ than control plants on days 14 and 18 . The WUE $\left(\mathrm{A}_{\mathrm{CO} 2} / \mathrm{E}\right)$ increased in plants grown in 800 $\mu \mathrm{mol} \cdot \mathrm{mol}^{-1} \quad \mathrm{CO}_{2}$ as the experiment advanced (Fig. 3). The WUE increased in plants cultured with high $\mathrm{CO}_{2}$ reaching values between 11 and 13 at the end of the experiment, whereas the WUE in control plants was around 4 . The $\mathrm{Ci} / \mathrm{Ca}$ ratio increased only in plants cultured at elevated $\mathrm{CO}_{2}$ and sprayed with the Promalin ${ }^{\circledR}$ solution on day 7 (Fig. 3). No differences among treatments were found on the rest of the days, except day 14.

Chlorophyll content. High $\mathrm{CO}_{2}$ induced a significant increment in the amount of Chl $a$, whereas it decreased the amounts of $\mathrm{Chl} b$ and Chl $a+b$ compared with plants cultured in control $\mathrm{CO}_{2}$ (Table 2). Differences between control plants and plants sprayed with Promalin ${ }^{\circledR}$ were only found at ambient $\mathrm{CO}_{2}$, at which the Promalin ${ }^{\circledR}$ treatment provoked a significant increment in the amount of Chl $a$ and a decrease in Chl $b$ and Chl $a+b$.

Soluble sugars and starch. The soluble sugars content in the hypocotyls before planting was $76.24 \mathrm{~g} \cdot \mathrm{kg}^{-1} \mathrm{DW}$ (Table 2). This amount decreased after planting in all the treatments. Nonetheless, high $\mathrm{CO}_{2}$ softened this drop because the amount of soluble sugars detected in plants cultured in 800 $\mu \mathrm{mol} \cdot \mathrm{mol}^{-1} \mathrm{CO}_{2}$ was almost double than that in plants grown in ambient $\mathrm{CO}_{2}$. Promalin ${ }^{\circledR}$ did not vary the concentration of soluble sugars in plants grown in ambient $\mathrm{CO}_{2}$. However, it decreased the soluble sugars in plants cultured in high $\mathrm{CO}_{2}$. The initial hypocotyl starch concentration was 5.46 g. $\mathrm{kg}^{-1}$ DW (Table 2). The levels increased after transplanting, being significantly higher in plants cultured with high $\mathrm{CO}_{2}$.

\section{Discussion}

Seedlings are a major issue in any woody plant breeding program. However, all efforts have focused on ovule culture-neglecting the subsequent developmental stage, namely seedling growth and adaptation after germination. Previous studies have proved the effect of $\mathrm{CO}_{2}$ and Promalin ${ }^{\circledR}$ on the plant growth and/or yield of a few woody species, and this study assessed both effects, alone or combined, in plantlets after seed germination. Furthermore, a thorough physiological monitoring of the plants was carried out; this showed that they were better adapted to the environment and in a better physiological state when cultured with elevated $\mathrm{CO}_{2}$.

The primary and instantaneous responses to an increase in the $\mathrm{CO}_{2}$ concentration around the plant are an increased rate of photosynthesis and a decreased rate of transpiration at the leaf level (Poorter and Navas, 2003). Thus, the elevated concentration of $\mathrm{CO}_{2}$ increased $\mathrm{A}_{\mathrm{CO} 2}$ and WUE while no significant changes were generally detected in plants treated with Promalin ${ }^{\circledR}$. Promalin ${ }^{\circledR}$ is composed of plant growth regulators, which should intervene in plant growth through mechanisms different from those associated with photosynthesis. Cytokinins promote cell division in meristems (Morini and Melai, 2005) and GA is involved in plant elongation (Yilmaz and Ozguyen, 2009) that enhanced elongation but not general plant growth; ergo, Promalin ${ }^{\circledR}$ promoted plant height but not the number of leaves or LA. According to Morini and Melai (2005), this could be due to the elevated energy demand of this process. Notwithstanding, maybe this is not the only reason. Elevated $\mathrm{CO}_{2}$ has been reported to promote leaf expansion (Morison, 1993) and this effect was exhibited in our study by plants cultured in elevated $\mathrm{CO}_{2}$ and without Promalin ${ }^{\circledR}$. However, the combined effect of high $\mathrm{CO}_{2}$ and Promalin ${ }^{\circledR}$ produced a marked increase in plant height but was not able to overcome the effects of Promalin ${ }^{\circledR}$ on LA. Thus, the reduced production of leaves and the low LA were similar in both groups of plants treated with Promalin ${ }^{\circledR}$. This suggests that Promalin ${ }^{\circledR}$ inhibits leaf development in favor of plant elongation. This response could be genotype-dependent because Goenaga (2010) did not find any change in plant height, stem diameter, number of branches, or number of leaves in mangosteen seedlings treated with Promalin ${ }^{\circledR}$. Also, this is the opposite of the findings of Emongor et al. 

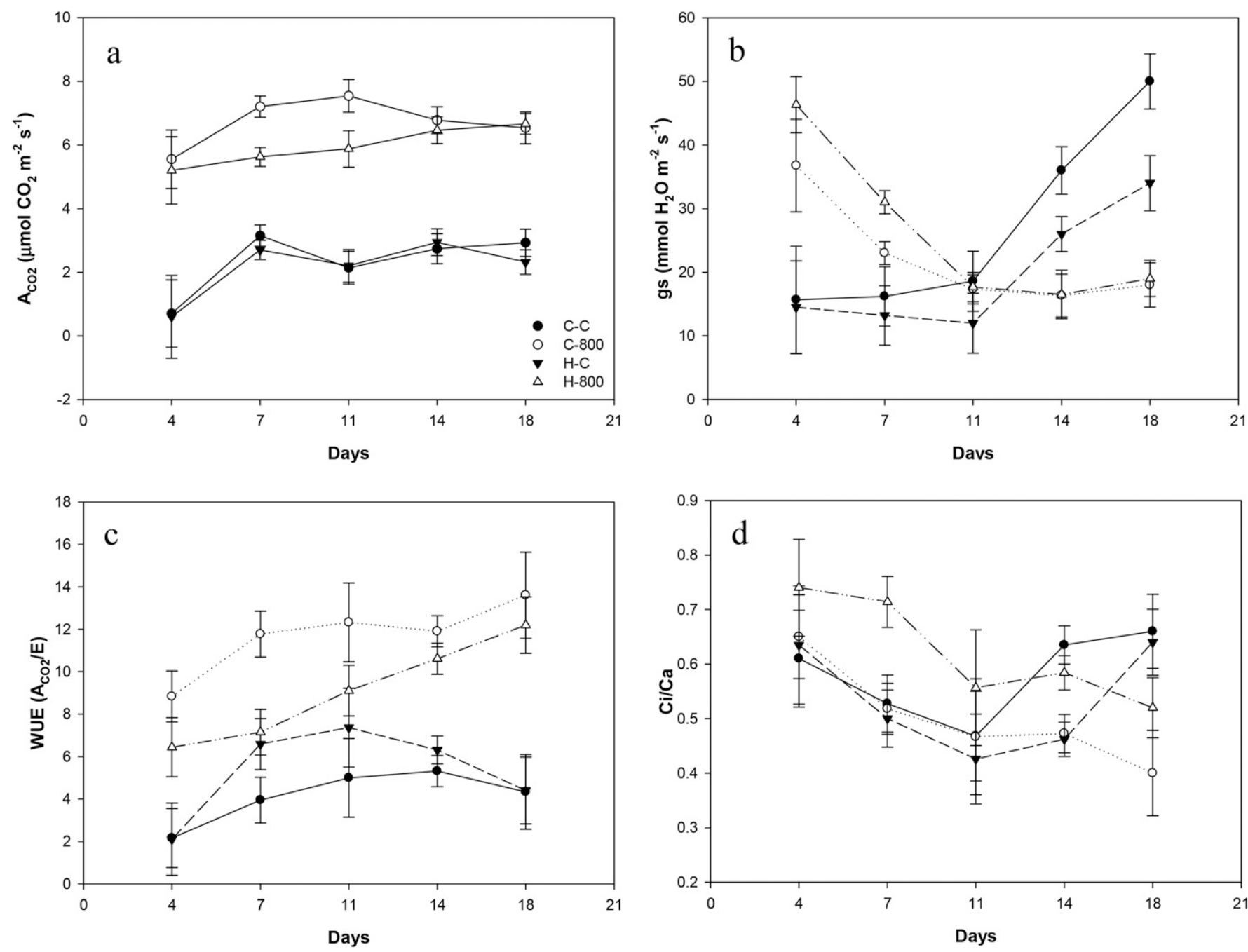

Fig. 3. Net $\mathrm{A}_{\mathrm{CO} 2}$ rate $(\mathbf{A})$, stomatal conductance $\left(g_{\mathrm{s}}\right),(\mathbf{B})$ water use efficiency (WUE) $\left(\mathrm{A}_{\mathrm{CO} 2} / \mathrm{E}\right),(\mathbf{C})$ the internal $\mathrm{CO}_{2}$ concentration/ambient $\mathrm{CO}_{2}$ ratio, and $(\mathbf{D})$ of Prunus avium seedlings treated with Promalin ${ }^{\circledR}$ and $800 \mu \mathrm{mol} \cdot \mathrm{mol}^{-1} \mathrm{CO}_{2}(\mathrm{H}-800)$ or the ambient concentration of $\mathrm{CO}_{2}(\mathrm{H}-\mathrm{C})$, or without Promalin ${ }^{\circledR}$ in $800 \mu \mathrm{mol} \cdot \mathrm{mol}^{-1} \mathrm{CO}_{2}(\mathrm{C}-800)$ or the ambient concentration of $\mathrm{CO}_{2}(\mathrm{C}-\mathrm{C})$. Values are means $\pm \mathrm{SE}(n=10)(P<0.05)$.

Table 2. The chlorophyll $a(\mathrm{Chl} a), b(\mathrm{Chl} b), a+b(\mathrm{Chla} a+b)$, soluble sugars, and starch contents of Prunus avium seedlings treated with Promalin ${ }^{\circledR}$ and $800 \mu \mathrm{mol} \cdot \mathrm{mol}^{-1} \mathrm{CO}_{2}(\mathrm{P}-800)$ or the ambient concentration of $\mathrm{CO}_{2}(\mathrm{P}-\mathrm{C})$, or without Promalin ${ }^{\circledR}$ in $800 \mu \mathrm{mol} \cdot \mathrm{mol}^{-1} \mathrm{CO}_{2}(\mathrm{C}-800)$ or the ambient concentration of $\mathrm{CO}_{2}(\mathrm{C}-\mathrm{C})$ before and after the experiment. Values are means $\pm \mathrm{SE}(n=10)(P<0.05)$.

\begin{tabular}{|c|c|c|c|c|c|}
\hline & \multirow[b]{2}{*}{ START } & \multicolumn{2}{|c|}{400} & \multicolumn{2}{|c|}{800} \\
\hline & & $\mathrm{C}$ & $\mathrm{P}$ & $\mathrm{C}$ & $P$ \\
\hline $\mathrm{Chl} b$ & - & $3.570 \pm 0.062 \mathrm{a}$ & $3.007 \pm 0.066 \mathrm{~b}$ & $2.408 \pm 0.141 \mathrm{c}$ & $2.452 \pm 0.089 \mathrm{c}$ \\
\hline Starch $\left(\mathrm{g} \cdot \mathrm{kg}^{-1}\right)$ & $5.467 \pm 0.142 \mathrm{c}$ & $8.360 \pm 0.650 \mathrm{~b}$ & $9.206 \pm 0.185 b$ & $11.195 \pm 0.837 \mathrm{a}$ & $11.584 \pm 0.279 \mathrm{a}$ \\
\hline
\end{tabular}

(2004), who described an increase in the total LA, plant height, and leaf number in Brassica oleracea plants. Despite the phenomena described previously, the limited number of leaves and the decreased LA did not reduce the photosynthesis rate of plants treated with Promalin ${ }^{\circledR}$

On the other hand, the imbalance between leaf growth and elongation may be related with the lower number of plants in active growth and with the higher mortality of plants sprayed with Promalin ${ }^{\circledR}$. Per contra, $\mathrm{CO}_{2}$ augmentation provoked a decrease in mortality and a larger amount of plants in active growth; it also produced an increase in $\mathrm{A}_{\mathrm{CO} 2}$, WUE, soluble sugars, and starch, resulting in plants more physiologically prepared for transfer to the field or greenhouse.

The results concerning $g_{\mathrm{s}}$ were noteworthy. Low concentrations of $\mathrm{CO}_{2}$ are associated with increased $g_{\mathrm{s}}$ (Beerling and Chaloner, 1993), whereas high $\mathrm{CO}_{2}$ induces low $g_{\mathrm{s}}$ (Harley et al., 1992). This is supported by the results of Centritto et al. (1999), who detected a significant reduction in $g_{\mathrm{s}}$ in cherry tree seedlings at elevated $\mathrm{CO}_{2}$. By contrast, plants grown under elevated $\mathrm{CO}_{2}$ exhibited higher $g_{\mathrm{s}}$ in the first two samplings of our experiment, when compared with control plants, although the situation was reversed in the last two samplings of the experiment. The seedlings used in this experiment had no leaves when the experiment started. Thus, the stomata of the first leaves could not have been well-developed during the first stages, and the response of the stomata to the high $\mathrm{CO}_{2}$ concentration was the opposite of what was expected. After this initial period, the stomata started to react to the high $\mathrm{CO}_{2}$ concentration and began to close. Similar results were detected in peach tree seedlings (Centritto et al., 2002), apple leaves (Brainerd and 
Fuchigami, 1982), and cherry tree (Druta, 2001). By contrast, the $g_{\mathrm{s}}$ in control plants started to increase as a response to the higher water demand arising from the plant development and growth.

Photosynthetic pigments play an important role in photosynthesis, absorbing light, and transferring energy. A low chlorophyll content can reduce light harvesting affecting photosynthesis (Druta, 2001). The Promalin ${ }^{\circledR}$ and $\mathrm{CO}_{2}$ treatments affected the chlorophyll content. Promalin ${ }^{\circledR}$ treatment decreased chl $b$ while it increased chl $a$. GA has been previously presented as a delayer of chl degradation (Gambetta et al., 2014; Jordi et al., 1995; Wachowicz et al., 2006) what would be according with our results in chl $a$ but contrary to our findings in chl $b$. Although cytokinins are able to promote chl biogenesis (Dobránszki and MendlerDrienyovszki, 2014) many studies have shown that GA and cytokinin exert antagonistic effects, where cytokinins inhibit the production of GA and promote its deactivation and GA inhibit cytokinin responses (Weiss and Ori, 2007). This interaction could be responsible of the contrasting results obtained by Promalin ${ }^{\circledR}$ in this experiment. Nevertheless, the effects of Promalin ${ }^{\circledR}$ were overcome by the action of high $\mathrm{CO}_{2}$. This is opposite to the findings of Centritto et al. (1999) in sweet cherry, where the chlorophyll concentration of seedlings was unaffected by elevated $\mathrm{CO}_{2}$. The general decrease in chlorophylls could be a response to autotrophic conditions (Dias et al., 2013). During germination, the plants grew using seed reserves; after that stage, the plants grown in elevated $\mathrm{CO}_{2}$ were able to maintain higher carbohydrates concentrations through the increase in the photosynthetic rate. On the contrary, the plants grown in control conditions needed to increase the amount of chlorophylls to enhance the photosynthetic apparatus. This is supported by the higher concentrations of soluble sugars and starch detected in plants cultured in high $\mathrm{CO}_{2}$ when compared with control plants.

In conclusion, an elevated $\mathrm{CO}_{2}$ concentration provoked an increase in the photosynthesis rate and WUE as well as in the levels of soluble sugars and starch. All these parameters contributed to the fact that the plants grown in high $\mathrm{CO}_{2}$ exhibited better growth and physiological status. Promalin ${ }^{\circledR}$ also increased plant height, even more so than augmentation of the $\mathrm{CO}_{2}$ supply. However, the growth of plants treated with Promalin ${ }^{\circledR}$ was unbalanced, which probably produced the observed increase in plant mortality. This study has exposed the beneficial effect that $\mathrm{CO}_{2}$ may confer on seedlings in the very sensitive postgermination stage. Thus, $\mathrm{CO}_{2}$ fertilization can improve the quality, growth, and survival of cherry tree seedlings.

\section{Literature Cited}

Arbeloa, A., M.E. Daorden, E. García, P. Andreu, and J.A. Marín. 2009. In vitro culture of 'Myrobalan' (Prunus cerasifera Ehrh.) embryos. HortScience 44:1672-1674.
Brainerd, K.E. and L.H. Fuchigami. 1982. Stomatal functioning of in vitro and greenhouse apple leaves in darkness, mannitol, $\mathrm{ABA}$ and $\mathrm{CO}_{2}$. $\mathrm{J}$. Expt. Bot. 33:388-392.

Beerling, D.J. and W.G. Chaloner. 1993. Evolutionary responses of stomatal density to global $\mathrm{CO}_{2}$ Change. Biol. J. Linn. Soc. Lond. 48:343-353.

Buysse, J. and R. Merckx. 1993. An improved colorimetric method to quantify sugar content of plant tissue. J. Expt. Bot. 44:1627-1629.

Carrasco, B., L. Meisel, M. Gebauer, R. GarciaGonzales, and H. Silva. 2013. Breeding in peach, cherry and plum: From a tissue culture, genetic, transcriptomic and genomic perspective. Biol. Res. 46:219-230.

Centritto, M., M.E. Lucas, and P.G. Jarvis. 2002. Gas exchange, biomass, whole-plant water-use efficiency and water uptake of peach (Prunus persica) seedlings in response to elevated carbon dioxide concentration and water availability. Tree Physiol. 22:699-706.

Centritto, M., F. Magnani, H.S.J. Lee, and P.G. Jarvis. 1999. Interactive effects of elevated $\left[\mathrm{CO}_{2}\right]$ and drought on cherry (Prunus avium) seedlings II. Photosynthetic capacity and water relations. New Phytol. 141:141-153.

Chaves, M.M. 1994. Environmental constraints to photosynthesis in ex vitro plants, p. 1-8. In: P.J. Lumsden, J.R. Nicholas, and W.J. Davies (eds.). Physiology, growth and development of plants in culture. Kluwer Academic Publishers, Dordrecht, The Netherlands.

del Amor, F.M., P. Cuadra-Crespo, D.J. Walker, J.M. Camara, and R. Madrid. 2010. Effect of foliar application of antitranspirant on photosynthesis and water relations of pepper plants under different levels of $\mathrm{CO}_{2}$ and water stress. J. Plant Physiol. 167:1232-1238.

Dias, M.C., G. Pinto, C. Guerra, C. Jesus, J. Amaral, and C. Santos. 2013. Effect of irradiance during acclimatization on content of proline and phytohormones in micropropagated Ulmus minor. Biol. Plant. 57(4):769-772.

Dobránszki, J. and N. Mendler-Drienyovszki. 2014. Cytokinin-induced changes in the chlorophyll content and fluorescence of in vitro apple leaves. J. Plant Physiol. 171:1472-1478.

Druta, A. 2001. Effect of long term exposure to high $\mathrm{CO}_{2}$ concentrations on photosynthetic characteristics of Prunus avium L. plants. Photosynthetica 39(2):289-297.

Emongor, V., F. Pule-Meulenberg, and O. Pholes. 2004. Effect of Promalin on growth and development of kale (Brassica oleracea L. var. Acephala DC). J. Agron. 3:208-214.

Gambetta, G., V. Mesejo, A. Martinez-Fuentes, C. Reig, A. Gravina, and M. Agusti. 2014. Gibberellic acid and norflurazon affecting the timecourse of flayed pigment and abscisic acid content in 'Valencia' sweet orange. Sci. Hort. 180:94-101.

Goenaga, R. 2010. Evaluation of Promalin to promote growth of young mangosteen seedlings. J. Agr. Univ. P.R. 94(3-4):105-109.

Harley, P.C., R.B. Thomas, J.F. Reynolds, and B.R. Strain. 1992. Modelling photosynthesis of cotton grown in elevated $\mathrm{CO}_{2}$. Plant Cell Environ. 15:271-282.

Jordi, W., G.M. Stoopen, K. Kelepouris, and W.M. van der Krieken. 1995. Gibberellin-induced delay of leaf senescence of Alstroemeria cut flowering stems is not caused by an increase in the endogenous cytokinin content. J. Plant Growth Regul. 14(3):121-127.

Kuden, A.B., E. Tanriver, H. Gulen, and S. Buyukalaca. 1999. Embryo rescue of peach hybrids. Acta Hort. 484:531-533.
Marin, J.A. 2003. High survival rates during acclimatization of fruit tree rootstocks by increasing exposure to low relative humidity. Acta Hort. 616:139-142.

Morini, S. and M. Melai. 2005. Net $\mathrm{CO}_{2}$ exchange rate of in vitro plum cultures during growth evolution at different photosynthetic photon flux density. Sci. Hort. 105:197-211.

Morison, J.I.L. 1993. Response of plants to $\mathrm{CO}_{2}$ under water limited conditions. Vegetatio 104/ 105:193-209.

Pérez Jiménez, M., A.J. López-Pérez, G. OtáloraAlcón, D. Marín-Nicolás, M.C. Piñero, and F.M. del Amor. 2015. A regime of high $\mathrm{CO}_{2}$ concentration improves the acclimatization process and increases plant quality and survival. Plant Cell Tissue Organ Cult. 121(3): 547-557.

Porra, R.J., W.A. Thompson, and P.E. Kriedemann. 1989. Determination of accurate extinction coefficients and simultaneous-equations for assaying chlorophyll a and chlorophyll b extracted with 4 different solvents: Verification of the concentration of chlorophyll standards by atomic-absorption spectroscopy. Biochim. Biophys. Acta 975:384-394.

Poorter, H. and M.-L. Navas. 2003. Plant growth and competition at elevated $\mathrm{CO}_{2}$ : On winners, losers and functional groups. New Phytol. 157:175-198.

Rossi, A.D., L. Rufato, C.L. Giacobbo, F.R.C Gomez, and J.C. Fachineno. 2004. Use of promalin ${ }^{\circledR}$ on one-year old trees of the apple cv. Catarina. Acta Hort. 636:145-149.

Saralabai, V.C., M. Vivekanandan, and R. Suresh Babu. 1997. Plant responses to high $\mathrm{CO}_{2}$ concentration. Photosynthetica 33(1):7-37.

Sharma, D.R., R. Kaur, and K. Kumar. 1996. Embryo rescue in plants-A review. Euphytica 89:325-337.

Socolowski, F. and S.M. Cicero. 2011. Use of growth regulators to overcome seed dormancy in Xylopia aromatica (Annonaceae). Seed Sci. Technol. 39(1):21-28.

Veinbrants, N. and P. Miller. 1981. Promalin promotes lateral short development of young cherry trees. Austral. J. Expt. Agr. 21:618622.

Wachowicz, M., E. Skutnik, and J. RabizaŚwider. 2006. The effect of growth regulators on stomatal aperture in senescing cut leaves of Zantedeschia aethiopica Spr. and Hosta Tratt. 'Undulata Erromena'. Folia Hort. 18 (2):65-75.

Walker, D.J., P. Romero, A. de Hoyos, and E. Correal. 2008. Seasonal changes in cold tolerance, water relations and accumulation of cations and compatible solutes in Atriplex halimus L. Environ. Expt. Bot. 64: 217-224.

Wang, F.L., H. Wang, and G. Wang. 2007. Photosynthetic responses of apricot (Prunus armeniaca $\mathrm{L}$.) to photosynthetic photon flux density, leaf temperature, and $\mathrm{CO}_{2}$ concentration. Photosynthetica 45(1):59-64.

Weiss, D. and N. Ori. 2007. Mechanisms of cross talk between gibberellin and other hormones. Plant Physiol. 144(3):1240-1246.

Wullschleger, S.D., T.J. Tschaplinski, and R.J. Norby. 2002. Plant water relations at elevated $\mathrm{CO}_{2}$ implications for water limited environments. Plant Cell Environ. 25:319-331.

Yilmaz, C. and A.I. Ozguyen. 2009. The effects of some plant nutrients, gibberellic acid and pinolene treatments on the yield, fruit quality and cracking in pomegranate. Acta Hort. 818:205212. 